\title{
Effects of historic wildfire and prescribed fire on site occupancy of bats in Shenandoah National Park, Virginia, USA
}

\author{
Lauren V. Austin ${ }^{1}$ Alexander Silvis ${ }^{1,2} \cdot$ W. Mark Ford ${ }^{3} \cdot$ Karen E. Powers $^{4}$
}

Received: 26 February 2018/Accepted: 24 May 2018/Published online: 4 April 2019

(C) This is a U.S. government work and its text is not subject to copyright protection in the United States; however, its text may be subject to foreign copyright protection. 2019

\begin{abstract}
Given the likelihood of regional extirpation of several once-common bat species in eastern North America from white-nose syndrome, it is critical that the impacts of forest management activities, such as prescribed fire, are known in order to minimize potentially additive negative effects on bat populations. Historic wildfires may offer a suitable surrogate to assess long-term burn impacts on bats for planning, implementing and assessing burn programs. To examine the effects of historic fire on bats, we sampled bat activities at 24 transect locations in burned and unburned forest stands in the central Appalachian Mountains of Shenandoah National Park (SNP), Virginia, USA. There was limited evidence of positive fire effects over time on hoary bats (Lasiurus cinereus Beauvois) and big brown bats (Eptesicus fuscus Beauvois) occupancy.
\end{abstract}

Project funding: This work was supported by the Joint Fire Science Program (Grant \# G14AC00316) and National Park Service Whitenose Syndrome Program (Grant \#P14AC01042) through the Southern Appalachian Cooperative Ecosystem Studies Unit at Virginia Tech.

The online version is available at http://www.springerlink.com

Corresponding editor: Hu Yanbo.

W. Mark Ford

wmford@vt.edu

1 Department of Fish and Wildlife Conservation, Virginia Tech, Blacksburg, VA 24061, USA

2 Resource Environmental Solutions, Warrenton, VA 20187, USA

3 U.S. Geological Survey, Virginia Cooperative Fish and Wildlife Research Unit, Blacksburg, VA 24061, USA

4 Biology Department, Radford University, Radford, VA 24141, USA
Overall, there were few or mostly equivocal relationships of bat occupancy relative to burn conditions or time since fire in SNP across species using a false-positive occupancy approach. Our results suggest that fire does not strongly affect bat site occupancy short- or long-term in the central Appalachians.

Keywords Appalachian mountains - Bats · False-positive occupancy $\cdot$ Prescribed fire $\cdot$ Wildfire

\section{Introduction}

Fire suppression efforts in the early half of the 20th century have resulted in profound shifts in forest composition in eastern North America (Abrams 1992). In the absence of fire, advance regeneration of oaks (Quercus spp.) have been replaced by shade-tolerant species such as red maple (Acer rubrum L.). In Appalachian Mountain forests, this has resulted in dense, shade-tolerant understories and midstories and the eventual failure of oaks to reach the overstory either following harvesting or in gap-phase dynamic processes (Abrams 1992; Signell et al. 2005; Brose et al. 2011). As such, prescribed fire is increasingly being used to maintain or restore fire-dependent communities, particularly to promote successful oak regeneration (USDA Forest Service 2006; Hessl et al. 2011; Strahan et al. 2015; Block et al. 2016; Hessburg et al. 2016; Iverson et al. 2017). However, after years of fire suppression, it generally is unknown how fire impacts wildlife in these systems or how long these impacts, either positive or negative, persist (Keyser and Ford 2006; Ford et al. 2010; Perry 2012). 
In the central Appalachians, bats are of particular conservation concern (Ingersoll et al. 2013) due to extreme population declines of many cave-dwelling species as a result of white-nose syndrome (WNS; Frick et al. 2010; Francl et al. 2012), and of migratory species as a result of wind energy development (Arnett et al. 2008; Arnett and Baerwald 2013; Erickson et al. 2016). Given the high likelihood of regional extirpation or extinction of several once-common bat species (Frick et al. 2010; Thogmartin et al. 2013), it is critical that the impacts of forest management activities, such as prescribed fire on bats, are known in order to minimize potentially additive negative effects relative to the stressors of WNS or wind energy. Regionally, prescribed fire is used as a stewardship tool to accomplish an array of different forest management objectives that benefit wildlife, (e.g., fuel reduction, oak regeneration, savanna creation; Abrams 1992; Peterson and Reich 2001; Nowacki and Abrams 2008; Harper et al. 2016). However, because three bat species in the central Appalachians are protected under the United States Endangered Species Act and two additional species are under status review, fire use faces regulatory scutiny due to the potential for direct or indirect harm to bats. The threatened northern long-eared bat (Myotis septentrionalis Trouessart) and the endangered Indiana bat (Myotis sodalis Miller \& Allen) are of particular conservation concern because both species day-roost and forage in upland forests during the non-hibernation, maternity season (Silvis et al. 2016b). Potential negative impacts of fire on bats include direct mortality from smoke inhalation, flame immolation, habitat and roost loss, or disruption of group dynamics (Carter et al. 2000; Boyles and Aubrey 2006; Dickinson et al. 2010; Perry and McDaniel 2015). Conversely, fire may benefit bats through reduction or modification of clutter from tree, branch and foliage density that facilitates flight, increased foraging efficiency, snag/roost creation, and increased insect prey abundance (Loeb and Waldrop 2008; Perry 2012; Ford et al. 2016; Silvis et al. 2016a).

Throughout eastern North America, including the central Appalachians, pre-WNS research on bat communities has found species-specific responses to prescribed fire, but notably overall bat activity often is higher in burned than in unburned areas (Ford et al. 2006; Loeb and Waldrop 2008; Smith and Gehrt 2010; Armitage and Ober 2012; Cox et al. 2016; Silvis et al. 2016a). Bat species-specific habitat selection is related in part to wing morphology and echolocation characteristics that influence maneuverability and foraging strategies (Aldridge and Rautenbach 1987; Norberg and Rayner 1985). Considerable research has documented differences in likelihood of species presence relative to forest vegetation structure (Adams et al. 2009; Plank et al. 2012; Müller et al. 2013), and that structural clutter is more influential than prey abundance in determining bat habitat use (Cox et al. 2016). It seems likely, then, that prescribed fire benefits bat communities in the short-term through reductions in structural clutter that improve foraging efficiency (Grindal and Brigham 1998; Titchenell et al. 2011; Müller et al. 2013), particularly for larger-bodied, less maneuverable species such as the big brown bat (Eptesicus fuscus) and the hoary bat (Lasiurus cinereus) (Loeb and Waldrop 2008; Silvis et al. 2016a). For some larger-bodied species, such as the eastern red bat (Lasiurus borealis Müller) (Starbuck et al. 2015; Silvis et al. 2016a), because it is a habitat generalist (Hutchinson and Lacki 1999; Ford et al. 2005), the probability of occurrence and/or activity levels has been found to be similar between burned and unburned forests.

Foraging activity of northern long-eared and Indiana bats, both smaller-bodied species adapted to cluttered environments, has been found to differ immediately preand post-fire in the central Appalachians (Dickinson et al. 2009; Lacki et al. 2009); however their foraging patterns return to pre-burn patterns within weeks (Dickinson et al. 2009). Likewise, the Indiana bat home range size (Lacki et al. 2009) and that of the northern long-eared bat (Johnson et al. 2009), and the Indiana bat's roost switching frequency (Johnson et al. 2010b), have not been found to change in response to prescribed burning, suggesting that roost availability is likely comparable between burned and unburned areas. In a direct assessment of long-term potential roost availability following prescribed fire, Ford et al. (2016) found that the availability of trees with characteristics suitable for northern long-eared bat roosting, (e.g., cavities and loose bark), increased post-fire, although tree species composition of the available pool of suitable roosts changed. Roost trees in burned areas may be more suitable for bats than those in unburned areas due to overall increased solar exposure resulting from canopy dieback of neighboring trees, allowing for increased light penetration that aids in thermoregulation and expedites juvenile development (Zahn 1999; Boyles and Aubrey 2006; Johnson et al. 2009). Collectively, these studies suggest that northern long-eared and Indiana bats may be unaffected by or display a slight positive response to fire in the Appalachians.

Nonetheless, little is currently known about the longterm effects of fire on bats in the central Appalachians, or the effects relative to WNS-impacted bat populations and communities, as most previous research occurred preWNS. These topics have important implications both for long-term forest management and conservation of threatened and endangered bats. Although there are increasing numbers of prescribed burns in the central Appalachians (Brose et al. 2011), it is a small percentage annually $(<5 \%)$ of public lands overall (USDA Forest Service 2014; Young et al. 2017), and the limited history of 
prescribed fire precludes assessment of the long-term impacts of fire. Historic wildfires, although variable in intensity and size than prescribed fires on nearby national forest or state lands (Austin et al. 2018), offer a pragmatic surrogate to assess long-term burn impacts on bats that can be used to better incorporate both bat and fire ecology into land management plans. Our objectives, therefore, were to assess patterns of site occupancy by bat species among variously aged burned stands and paired unburned stands in the central Appalachians. We hypothesized that the probability of occurrence would differ between paired burned and unburned stands by species, with higher occupancy in burned stands than in unburned stands for larger-bodied bats due to reduced clutter that facilitates flight, and perhaps for all species due to increased insect abundance. Additionally, we hypothesized that the probability of occurrence for all bat species would decrease with increasing burn age, as forest structural clutter increases, particularly for the Mytois genus of bats.

\section{Materials and methods}

\section{Study area}

The study was conducted in Shenandoah National Park (SNP) that encompasses 79,900 ha within the Blue Ridge province of the central Appalachian Highlands and spans eight Virginian counties: Warren, Page, Rockingham, Augusta, Rappahannock, Madison, Greene, and Albemarle. The elevation ranges from 171 to $1235 \mathrm{~m}$. Previous inventory and monitoring efforts by Young et al. (2009) identified 35 unique vegetation communities that can, in part, be attributed to SNP's disturbance history of forest harvesting, grazing, and burning prior to park acquisition in the 1930s. Plant communities vary based on aspect and elevation, with northwest facing slopes harboring more chestnut oak (Quercus montana Willd.) and northern red oak (Quercus rubra L.) with some montane basswood (Tilia americana L.) and white ash (Fraxinus americana L.) found in circumneutral to basic boulder fields. High elevation $(>900 \mathrm{~m})$ ridge top forests are primarily comprised of stunted chestnut oak, yellow birch (Betula alleghaniensis Britt.), and northern red oak, with shrublands, consisting of mountain laurel (Kalmia latifolia L, black huckleberry (Gaylussacia baccata Koch), and Vaccinium spp. dominating cliffs and emergent rock outcrops. Low to mid-elevation (approximately 300-900 m) sheltered coves are typically dominated or co-dominated by sugar maple (Acer saccharum Marshall), but can also contain tulip poplar (Liriodendron tulipifera L.), white pine (Pinus strobus L.), eastern hemlock (Tsuga canadensis Carriére), and mixed hardwoods, depending on elevation and site fertility. Southeast facing slopes are often more varied, also consisting of cove and woodland species. Dry to moderately mesic forests typically comprised of chestnut oak, northern red oak, white oak (Quercus alba L.), pignut hickory (Carya glabra Miller), and Vaccinium spp. dominate northwest facing slopes; white pine is occasionally found on valley bottoms. Pine-oak/heath woodlands, consisting of table mountain pine (Pinus pungens Lamb.), pitch pine (Pinus rigida Mill.), and chestnut oak, are located on the most xeric and infertile soils of steep, highly solar-exposed mid-slopes. Riparian areas dominated by eastern hemlock and white pine with rosebay rhododendron (Rhododendron maximum L.) understories are limited in extent, making up less than $2 \%$ of the park.

Although SNP occasionally has used prescribed fire to enhance public safety and to maintain overlooks and meadows or for exotic plant control, there has been largely no landscape-level application of prescribed fire in the park (Young et al. 2017). This is in contrast to the past decade on the adjacent George Washington National Forest where fire use has greatly expanded in scale as a land management tool (USDA Forest Service 2014). The majority of historic fires in SNP were accidental wildfires ignited by lightning strikes, park guests, or arsonists. Wildfire size ranged from approximately two to 7000 ha, with fires greater $>40$ ha occurring nearly every 5 years since 1933 and in four of the five past years. Approximately 24,010 ha have burned between 1933 and 2014 ( 30\% of total SNP area; M. Forder, SNP Fire Ecologist, pers. comm.). The time since wildfire at SNP ranged from 3 to 85 years and burn size ranged from 20 to 9322 hectares (Fig. 1).

\section{Data collection}

We collected acoustic data from 11 June to 15 August 2015 using Songmeter ZC frequency-division bat detectors (Wildlife Acoustics, Maynard, Massachusetts, USA). Sampling during this period enabled us to investigate maternity season habitat associations in relation to fire, and when bats are most abundant on the SNP landscape and distributed throughout the park (Whitaker and Rissler 1992; Caceres and Barclay 2000; Ford et al. 2011). We programmed acoustic detectors to record data from 2000 to $0700 \mathrm{~h}$ and collected data for 11 days at each site. Bat activity was passively sampled at 11 transect locations that had paired burned and unburned stands, and an additional nine transects that only contained burned stands, and four transects that only contained unburned stands. Logistically practicable and accessible areas in SNP were identified and we distributed transects in these areas using generalized random tessellation stratified sampling which allowed for monitoring in areas of interest (i.e., burn habitat), while maintaining an approximate spatial-balance (Philippi 2013; 
Fig. 1 Bat detector and burn plot locations in Shenandoah National Park, Virginia, USA from 11 June to 15 August of 2015

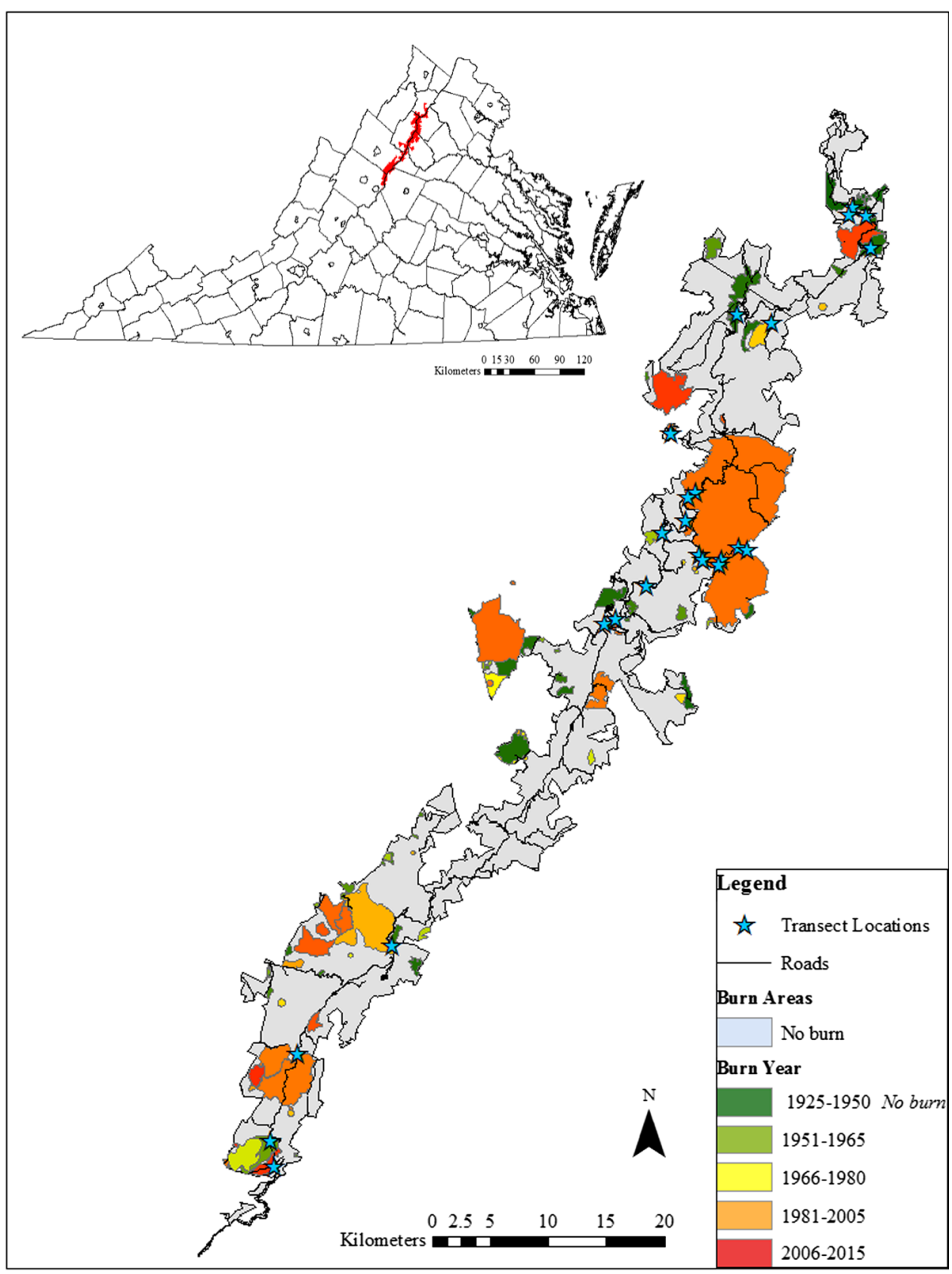

Fig. 1). Generally, transects contained three acoustic detectors at 160-meter intervals, with one deployed at the burned/unburned boundary, and one each in the burned and unburned habitats. Due to black bear (Urus americanus Pallas) interference with equipment within the region, detectors were secured directly to trees to minimize visibility. Areas that had a burned and unburned interface were prioritized to minimize landscape effects and enable us to attribute bat occupancy differences to habitat and burn variables of interest.

Following the protocol of Ford et al. (2005), call data, geo-referenced site location, canopy closure (spherical densitometer), and distance to nearest tree were collected in each cardinal direction at each survey site. The pointcentered quarter method was used to calculate tree density from distance to nearest tree, ultimately providing information on stand structure (Mitchell 2010). Elevation (m), aspect, and slope (degrees) were derived using digital elevation models available online through the U.S. Geological Survey (http://data.geocomm.com/dem/), and burn history from SNP management records (Table 1). We sinetransformed aspect following the protocol of Garst (2007). Data for weather covariates that could impact detectability of bats (i.e., temperature, wind speed, humidity, and 
Table 1 Covariates of interest for occupancy, detection, and false-positive detection for bat species in Shenandoah National Park, Virginia, USA

\begin{tabular}{|c|c|c|}
\hline Variable & Description & Units/categories \\
\hline Burn condition & $\begin{array}{l}\text { Whether the site was burned, unburned, or edge } \\
\text { habitat }\end{array}$ & Categorical: burned, unburned, edge \\
\hline Burn size & $\begin{array}{l}\text { Number of hectares burned in each individual } \\
\text { fire }\end{array}$ & Hectares \\
\hline Burn age & Number of years since last burn & Number \\
\hline Edge distance & $\begin{array}{l}\text { Meters between the acoustic site and fire } \\
\text { boundary }\end{array}$ & Meters \\
\hline Elevation & Meters above sea level & Meters \\
\hline Slope & Rate of change in elevation measured in degrees & Degrees \\
\hline Aspect & $\begin{array}{l}\text { Direction of the maximum rate of change in } \\
\text { slope; Sin- transformed }\end{array}$ & $\begin{array}{l}\text { Sine transformed so that } 0 \text { is north, } 0.49 \text { is east and } \\
\text { west, and } 1 \text { is south }\end{array}$ \\
\hline Canopy cover & $\%$ of sky covered by overstory vegetation & Percent \\
\hline Stem density & Average number of trees per hectare & Trees per hectare \\
\hline $\begin{array}{l}\text { Little brown bat (Myotis lucifugus) } \\
\text { presence }\end{array}$ & $\begin{array}{l}\text { Whether or not little brown bats are detected at } \\
\text { the site }\end{array}$ & Categorical: present or absent \\
\hline $\begin{array}{l}\text { Northern long-eared bat (Myotis } \\
\text { septentrionalis) presence }\end{array}$ & $\begin{array}{l}\text { Whether or not northern long-eared bats are } \\
\text { detected at a site }\end{array}$ & Categorical: present or absent \\
\hline Hoary bat (Lasiurus cinereus) presence & Whether or not hoary bats are detected at a site & Categorical: present or absent \\
\hline $\begin{array}{l}\text { Eastern red bat (Lasiurus borealis) } \\
\text { presence }\end{array}$ & $\begin{array}{l}\text { Whether or not eastern red bats are detected at a } \\
\text { site }\end{array}$ & Categorical: present or absent \\
\hline
\end{tabular}

precipitation), were obtained from the Meteorological Terminal Aviation Routine records at the airport nearest each detector site $(<21 \mathrm{~km})$.

\section{Data analyses}

\section{Bat call identification}

Calls were identified using both Kaleidoscope version 4.1.0, classifier version 3.1.0 at the sensitive setting (Wildlife Acoustics, Maynard, Massachusetts, USA), and Echoclass version 3.1 using species set 2 (U.S. Army Engineer Research and Development Center, Vicksburg, Mississippi, USA) matched for this portion of Virginia (Francl et al. 2011). Both programs are U.S. Fish and Wildlife Serviceapproved software versions (https:/www.fws.gov/midwest/ endangered/mammals/inba/surveys/inbaAcousticSoftware. html). Calls from 16 of 24 randomly selected transects ( $>50 \%$ of calls) were identified to species in AnalookW v. 3.9f (Titley Electronics, Ballina, NWS, Australia) to confirm that there were no major classification errors (i.e., classification of noise and insect calls as bats).

\section{Fire history effects}

Because bat calls are not perfectly identifiable by software (Russo and Voigt 2016), or visually (Jennings et al. 2008), acoustic data are highly likely to include false- positive determinations of a species presence in addition to false negatives. Although standard occupancy models are designed to deal with false negatives, they do not permit false positive detections of presence (Royle and Link 2006; Miller et al. 2011; Clement et al. 2014). To account for uncertainty in bat species detections, we modeled occupancy in relation to site characteristics and burn history using false-positive occupancy models in program $\mathrm{R}$ version 3.2.3 using package Unmarked (Fiske and Chandler 2011).

False-positive detection histories for bat species were created by comparing site-night presence determinations from Echoclass and Kaleidoscope (Table 1). Bats were considered to be present under each identification software if the maximum likelihood value for presence was $\leq 0.05$. Because we did not have a "certain" method to determine true presence, we considered agreement in site-night presence between the programs to represent "true" detection/non-detections, and disagreement to represent "uncertain" detections. False-positive output from our models therefore represent the likelihood of disagreement between software, rather than a true estimate of falsepositive detection.

Because we were interested in assessing effects of burn age and condition, while also accounting for other habitat condition effects that could influence bat presence, a series of a priori models were compared representing hypotheses about bat foraging habitat selection based on previous 
research (Ford et al. 2005; Kaiser and O'Keefe 2015). For each species, hypotheses were compared using a two-step modeling approach, wherein candidate detection and falsepositive models were ranked using Akaike's Information Criterion corrected for small sample size (AICc), with occupancy set to 1 and the best supported $(\triangle \mathrm{AICc}<2)$ model averaged combination was then used to model actual occupancy. Occupancy models representing our hypotheses were compared using AICc (Burnham and Anderson 2002). Due to a limited sample size, models were restricted to no more than five covariates. All covariates were centered and scaled before analyses. To account for uncertainty in the model selection process, a confidence set of models within $\Delta \mathrm{AICc}<2$ was identified as competing models, then used model averaged estimates, unconditional standard errors, and $95 \%$ confidence intervals to assess individual variable effects on probability of occurrence for each bat species of interest (Grueber et al. 2011; Symonds and Moussalli 2011)

For each species/group, a list of six detection models, seven false-positive models, and 11 state models were assessed. State models contained combinations of the following covariates: aspect, slope, elevation, canopy cover, tree density, burn year, and burn condition. Detection models included factors that may have influenced microphone performance (i.e., wind speed and precipitation), and factors that could obstruct a call from being recorded (i.e., canopy cover and tree density). False-positive models contained variables that may influence call quality (Broders et al. 2004; Clement et al. 2014), as well as nightly presence of species with similar call structures (Britzke et al. 2011; Russo and Voigt 2016). Species with similar call structure (for example, the Indiana bat versus the little brown bat), can be difficult to distinguish and thus likely have a higher probability of misidentification and false-positive detection rate.

\section{Results}

Across the 24 transects, a total of 71 individual detector sites (34 burned; 16 edge; 21 unburned) were surveyed for up to 11 nights each in 2015. Uneven sampling periods among sites were due to periodic detector failures caused by black bear damage or battery failure. Kaleidoscope identified 53,880 call files and detected nine unique species. Echoclass identified 22,799 call files and also detected nine unique species. Calls identified by both programs as silver-haired bats (Lasionycteris noctivagans Le Conte) were excluded from analyses due to high misclassification of big brown bat as this species. When visually examining calls, a systemic error was found whereby large quantities of insect noise were consistently being classified as hoary bat calls. To account for this issue, we visually examined all calls identified as hoary bats by Kaleidoscope using AnalookW v. 3.9f (Titley Electronics, Ballina, NWS, Australia), and removed all erroneously identified insect noise for that one software application. After removing the noise, calls were reanalyzed in Kaleidoscope to obtain corrected maximum likelihood estimates. Detection histories for false-positive covariates, (such as little brown bat presence), were generated such that, if either program identified the little brown bat as present, then it was assumed present.

\section{False-positive occupancy models}

\section{Big brown bat}

Kaleidoscope and Echoclass results agreed that big brown bats were detected at 17 of 71 sites, providing a "certain" naïve occupancy of 0.24. Either program, (but not both), designated big brown bats at an additional 36 sites, giving a possible naïve occupancy of 0.51 (Table 2). Two models were competing and contained combinations of burn condition, years since burn, tree density, and the presence of hoary bats, that had empirical support to describe occupancy, detection, and false-positive detection (Table 3). Burn condition and the interaction between burn condition and years since burn were the competing covariates for occupancy. The competing covariates for explaining detection and false-positive detection were tree density and presence of hoary bats, respectively. Confidence intervals for burn condition and the interaction between burn condition and years since burn overlapped zero and coefficients were small (Table 4). Tree density had a positive effect on detection (Fig. 2) and the presence of hoary bats had a positive effect on false-positive detection of big brown bats.

\section{Eastern red bat}

Kaleidoscope and Echoclass results agreed that eastern red bats were detected at 20 of 71 sites, providing a "certain" naïve occupancy of 0.28 (Table 2). Either program, (but not both), designated eastern red bats at an additional 49 sites, giving a possible naïve occupancy of 0.69. Two models were competing, one of which was the null. The other best-supported model contained slope, wind speed, and presence of little brown bats describing occupancy, detection, and false-positive detection, respectively (Table 3). Confidence intervals for slope overlapped zero and estimates were small (Table 4). Wind speed had a 
Table 2 Summary of site-level/ night-level agreement (out of 71 total sites/639 total nights) in species presence between Kaleidoscope and Echoclass for bat species, (except for hoary bat results which come from Kaleidoscope only), in Shenandoah National Park, Virginia, USA, 11 June to 2 August 2015

\begin{tabular}{llll}
\hline & Present & Absent & Disagree \\
\hline Big brown bat (Eptesicus fuscus) & $17 / 94$ & $18 / 370$ & $36 / 175$ \\
Hoary bat (Lasiurus cinereus) & $40 / 109$ & $31 / 530$ & - \\
Eastern red bat (Lasiurus borealis) & $20 / 32$ & $2 / 255$ & $49 / 352$ \\
Eastern small-footed bat (Myotis leibii)) & $1 / 1$ & $42 / 530$ & $28 / 108$ \\
Little brown bat (Myotis lucifugus) & $1 / 3$ & $34 / 470$ & $36 / 166$ \\
Northern long-eared bat (Myotis septentrionalis)) & $15 / 34$ & $19 / 429$ & $37 / 176$ \\
Indiana bat (Myotis sodalis) & $7 / 21$ & $33 / 491$ & $31 / 127$ \\
Tricolored bat (Perimyotis subflavus) & $4 / 9$ & $38 / 494$ & $29 / 136$ \\
\hline
\end{tabular}

Present, specifies the number of sites/nights that both Kaleidoscope and Echoclass agreed that each species was present; Absent, specifies the number of sites that both Kaleidoscope and Echoclass agreed that a species was absent; Disagree, indicates the number of sites that either Echoclass or Kaleidoscope said that a particular species was present but the other program did not negative effect on detection (Fig. 3). The estimate and unconditional standard errors for the presence of little brown bats were large, but had a positive effect on falsepositive detection of eastern red bats.

\section{Hoary bat}

Kaleidoscope detected hoary bats at 40 of 71 sites, providing a naïve occupancy of 0.56 (Table 2). There were four competing models containing combinations of an interaction between burn condition and elevation, tree density, wind speed, temperature, and canopy cover that had empirical support to describe occupancy and detection (Table 3). The interaction between burn condition, elevation, and tree density were the most important covariates predicting occupancy (Table 4). Wind speed, temperature, and canopy cover were the most important covariates for explaining detection. Confidence intervals for all state and detection variables overlapped zero and coefficients were small.

\section{Eastern small-footed bat}

Kaleidoscope and Echoclass were in agreement that eastern small-footed bats (Myotis leibii Audobon) were detected at 1 of 71 sites, providing a "certain" naïve occupancy of 0.01 (Table 2). Either program, (but not both), designated eastern small-footed bats at an additional 28 sites, giving a possible naïve occupancy of 0.39 . There was one competing model which consisted of slope, mean temperature, and little brown bat presence that had empirical support to described occupancy, detection, and false-positive detection, respectively (Table 3). Slope had a negative relationship with occupancy (Fig. 4a). Temperature had a positive relationship with detection (Fig. 4b) and the presence of little brown bats had a positive relationship with false-positive detection of eastern small-footed bats (Table 5).

\section{Little brown bat}

Kaleidoscope and Echoclass were in agreement that little brown bats (Myotis lucifugus LeConte) were detected at 1 of 71 sites, providing a "certain" naïve occupancy of 0.01 (Table 2). Either program (but not both) designated little brown bats at an additional 36 sites, giving a possible naïve occupancy of 0.51 . There was one competing model which consisted of an interaction between slope and burn condition, tree density, and northern long-eared bat presence that had empirical support to described occupancy, detection, and false-positive detection, respectively (Table 3). Confidence intervals for all state estimates overlapped zero (Table 5). Tree density had a positive relationship with detection (Fig. 5) and the presence of northern long-eared bats had a positive relationship with false-positive detection of little brown bats.

\section{Northern long-eared bat}

Kaleidoscope and Echoclass were in agreement that northern long-eared bats were detected at 15 of 71 sites, providing a "certain" naïve occupancy of 0.21 (Table 2). Either program, (but not both), designated northern longeared bats at an additional 37 sites, giving a possible naïve occupancy of 0.52 . There were three competing models containing combinations of slope, tree density, precipitation, and presence of little brown bats that had empirical support to describe occupancy, detection, and false positive detection (Table 3). Slope was the only competing covariate for occupancy. Tree density and binary precipitation were the competing covariates for detection. The presence of little brown bats was the competing covariate for false positive detection. Slope had a negative relationship with occupancy (Fig. 6). Confidence intervals for tree density and binary precipitation overlapped zero and coefficients were small (Table 4). With other covariates set 
Table 3 Competing $(\triangle \mathrm{AICc}<2)$ models and null model (state $=1)$ describing bat occupancy by species in Shenandoah National Park, Virginia, USA, 11 June to 2 August 2015

\begin{tabular}{|c|c|c|c|c|c|c|c|c|}
\hline Species & Detection & FP & State & $\mathrm{k}$ & $\mathrm{AICc}$ & $\Delta \mathrm{AICc}$ & Weight & LogLik \\
\hline \multirow[t]{3}{*}{ Big brown bat (Eptesicus fuscus) } & Tree density & LACI & $\begin{array}{l}\text { Burn condition } \\
\text { + burned*YSB }\end{array}$ & 9 & 780.17 & 0.00 & 0.38 & -379.61 \\
\hline & Tree density & LACI & Burn condition & 8 & 780.86 & 0.69 & 0.27 & -381.27 \\
\hline & Tree density & LACI & 1 & 6 & 782.76 & 2.59 & 0.10 & -384.72 \\
\hline \multirow[t]{6}{*}{ Eastern red bat (Lasiurus borealis) } & Wind speed & MYLU & 1 & 6 & 890.09 & 0.00 & 0.39 & -438.39 \\
\hline & Wind speed & MYLU & Slope & 7 & 891.74 & 1.65 & 0.17 & -437.98 \\
\hline & Wind speed & - & Burn condition*elevation & 8 & 543.97 & 0.00 & 0.18 & -262.82 \\
\hline & Temperature & - & burn condition*elevation & 8 & 544.79 & 0.82 & 0.12 & -263.24 \\
\hline & Wind speed & - & Tree density & 4 & 545.33 & 1.36 & 0.09 & -268.36 \\
\hline & $\begin{array}{c}\text { Canopy } \\
\text { cover }\end{array}$ & - & Burn condition*elevation & 8 & 545.91 & 1.94 & 0.07 & -263.79 \\
\hline \multirow[t]{2}{*}{ Eastern small-footed bat (Myotis leibii) } & Temperature & MYLU & Slope & 7 & 179.70 & 0.00 & 0.63 & -81.96 \\
\hline & Temperature & MYLU & 1 & 6 & 183.17 & 3.47 & 0.11 & -84.93 \\
\hline \multirow[t]{2}{*}{ Little brown bat (Myotis lucifugus) } & Tree density & MYSE & Burn condition*slope & 11 & 441.30 & 0.00 & 0.89 & -207.42 \\
\hline & Tree density & MYSE & 1 & 6 & 451.17 & 9.87 & 0.01 & -218.90 \\
\hline \multirow{4}{*}{$\begin{array}{l}\text { Northern long-eared bat (Myotis } \\
\text { septentrionalis) }\end{array}$} & Tree density & MYLU & Slope & 7 & 623.37 & 0.00 & 0.37 & -303.80 \\
\hline & Precipitation & MYLU & Slope & 7 & 624.44 & 1.07 & 0.22 & -304.33 \\
\hline & 1 & MYLU & Slope & 6 & 625.22 & 1.85 & 0.15 & -305.96 \\
\hline & Tree density & MYLU & 1 & 6 & 628.69 & 5.32 & 0.03 & -307.69 \\
\hline \multirow[t]{6}{*}{ Indiana bat (Myotis sodalis) } & $\begin{array}{c}\text { Canopy } \\
\text { cover }\end{array}$ & MYLU & 1 & 6 & 434.73 & 0.00 & 0.20 & -210.71 \\
\hline & $\begin{array}{c}\text { Canopy } \\
\text { cover }\end{array}$ & MYLU & Elevation & 7 & 434.83 & 0.09 & 0.19 & -209.52 \\
\hline & $\begin{array}{r}\text { Canopy } \\
\text { cover }\end{array}$ & MYLU & Burn condition*aspect & 11 & 435.41 & 0.67 & 0.14 & -204.47 \\
\hline & $\begin{array}{c}\text { Canopy } \\
\text { cover }\end{array}$ & MYLU & Aspect & 7 & 435.64 & 0.90 & 0.13 & -209.93 \\
\hline & $\begin{array}{c}\text { Canopy } \\
\text { cover }\end{array}$ & MYLU & Burn condition & 8 & 435.92 & 1.18 & 0.11 & -208.80 \\
\hline & $\begin{array}{c}\text { Canopy } \\
\text { cover }\end{array}$ & MYLU & Slope & 7 & 436.00 & 1.27 & 0.11 & -210.11 \\
\hline \multirow[t]{2}{*}{ Tricolored bat (Perimyotis subflavus) } & Tree density & MYLU & Slope & 7 & 351.86 & 0.00 & 0.56 & -168.04 \\
\hline & Tree density & MYLU & 1 & 6 & 354.76 & 2.89 & 0.13 & -170.72 \\
\hline
\end{tabular}

Occupancy was modeled with false-positive models except for the hoary bat which was modeled with single-season occupancy models with detection $=1$ if maximum likelihood estimator from identification software was $<0.05$

We present $k$ the number of parameters, AICc Akaike's Information Criteria for small sample size, $\triangle A I C c$ delta AICc, weight AICc weight, logLik log likelihood

at mean value, the presence of little brown bats had a strong, positive relationship with the probability of falsepositive detections of northern long-eared bats.

\section{Indiana bat}

Kaleidoscope and Echoclass were in agreement that Indiana bats were detected at 7 of 71 sites, providing a "certain" naïve occupancy of 0.10 (Table 2). Either program, (but not both), designated Indiana bats at an additional 31 sites, giving a possible naïve occupancy of 0.44 . There were six competing models, one of which was a null, containing combinations of slope, aspect, elevation, burn condition, canopy cover and presence of little brown bats that had empirical support to describe occupancy, detection, and false positive detection (Table 3). Slope, aspect, elevation, burn condition, and an interaction between burn condition and aspect were the competing covariates for estimating occupancy. Confidence intervals for all state covariates overlapped zero and coefficients were small 
Table 4 Model-averaged coefficients, unconditional standard errors (SE), parameter type for occupancy $(\Psi)$, detection $(\mathrm{p})$, and falsepositive detection (fp), and $95 \%$ upper and lower confidence intervals

\begin{tabular}{|c|c|c|c|c|c|c|}
\hline Species & Covariates & Parameter & Coefficient & SE & Lower CI & Upper CI \\
\hline \multirow[t]{5}{*}{ Big brown bat (Eptesicus fuscus) } & Burn condition: edge & $\Psi$ & 1.66 & 1.01 & -0.33 & 3.64 \\
\hline & Burn condition: burn & $\Psi$ & 0.11 & 0.9 & -1.65 & 1.88 \\
\hline & Burn condition: burn*YSB & $\Psi$ & -0.78 & 1.18 & -3.09 & 1.53 \\
\hline & Tree density & $\mathrm{p}$ & 0.74 & 0.35 & 0.05 & 1.42 \\
\hline & Hoary bat & $\mathrm{fp}$ & 3.59 & 0.31 & 2.98 & 4.19 \\
\hline \multirow[t]{6}{*}{ Hoary bat (Lasiurus cinereus) } & Burn condition edge*elevation & $\Psi$ & -1.56 & 1.53 & -4.56 & 1.44 \\
\hline & Burn condition Burn*elevation & $\Psi$ & 1.15 & 1.22 & -1.24 & 3.54 \\
\hline & Tree density & $\Psi$ & 0.13 & 0.32 & -0.49 & 0.75 \\
\hline & Wind speed & $\mathrm{p}$ & -0.19 & 0.18 & -0.53 & 0.16 \\
\hline & Temperature & $\mathrm{p}$ & -0.09 & 0.17 & -0.41 & 0.23 \\
\hline & Canopy cover & $\mathrm{p}$ & -0.05 & 0.12 & -0.28 & 0.18 \\
\hline \multirow[t]{3}{*}{ Eastern red bat (Lasiurus borealis) } & Slope & $\Psi$ & -0.09 & 0.24 & -0.55 & 0.37 \\
\hline & Wind speed & $\mathrm{p}$ & $-\mathbf{0 . 2 8}$ & 0.12 & -0.51 & -0.05 \\
\hline & Little brown bat & $\mathrm{fp}$ & 13.3 & 48.8 & -82.34 & 108.95 \\
\hline \multirow[t]{4}{*}{ Northern Long-eared Bat (Myotis septentrionalis) } & Slope & $\Psi$ & -1.10 & 0.49 & -2.06 & -0.14 \\
\hline & Tree density & $\mathrm{p}$ & 0.15 & 0.18 & -0.21 & 0.51 \\
\hline & Precipitation & $\mathrm{p}$ & 0.17 & 0.32 & -0.45 & 0.79 \\
\hline & Little brown bat & $\mathrm{fp}$ & 6.05 & 0.57 & 4.93 & 7.17 \\
\hline \multirow[t]{9}{*}{ Indiana bat Myotis sodalis) } & Elevation & $\Psi$ & 0.17 & 0.4 & -0.6 & 0.95 \\
\hline & Burn condition: edge*aspect & $\Psi$ & 0.70 & 1.82 & -2.88 & 4.27 \\
\hline & Burn condition: Burn*aspect & $\Psi$ & 0.39 & 1.14 & -1.84 & 2.63 \\
\hline & Aspect & $\Psi$ & -0.20 & 0.94 & -2.03 & 1.64 \\
\hline & Burn condition: edge & $\Psi$ & 0.49 & 1.18 & -1.83 & 2.81 \\
\hline & Burn condition: burn & $\Psi$ & 0.20 & 0.92 & -1.61 & 2.00 \\
\hline & Slope & $\Psi$ & -0.06 & 0.25 & -0.55 & 0.42 \\
\hline & Canopy cover & $\mathrm{p}$ & 0.63 & 0.25 & 0.14 & 1.12 \\
\hline & Little brown bat & $\mathrm{fp}$ & 5.19 & 0.53 & 4.14 & 6.23 \\
\hline
\end{tabular}

We present the parameter type, coefficient, $S E$ standard error, and $C I$ upper and lower confidence intervals

Estimates for covariates with confidence intervals that do not overlap zero are highlighted in bold

(Table 4). The competing covariates for explaining detection and false-positive detection were canopy cover and presence of little brown bats, respectively; both had a positive relationship with the presence of Indiana bats (Fig. 7).

\section{Tricolored bat $F$}

Kaleidoscope and Echoclass were in agreement that tricolored bats (Perimyotis subflavus Culvier) were detected at 4 of 71 sites, providing a "certain" naïve occupancy of 0.06 (Table 2). Either program, (but not both), designated tricolored bats at an additional 29 sites, giving a possible naïve occupancy of 0.41 . There was one competing model which consisted of slope, tree density, and little brown bat for competing bat occupancy models $(\triangle \mathrm{AICc}<2)$ by species in Shenandoah National Park, Virginia, USA, 11 June to 2 August 2015 


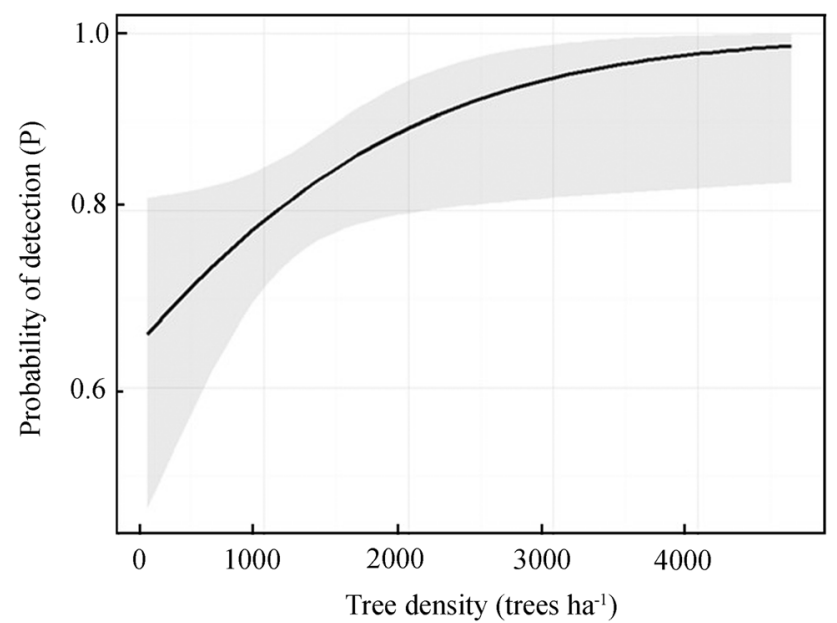

Fig. 2 Partial effects plot of the relationship between probability of detection of big brown bats (Eptesicus fuscus; with 95\% confidence intervals) and tree density (trees/ha) at Shenandoah National Park, Virginia, USA, 11 June to 15 August 2015], as identified in the averaged model

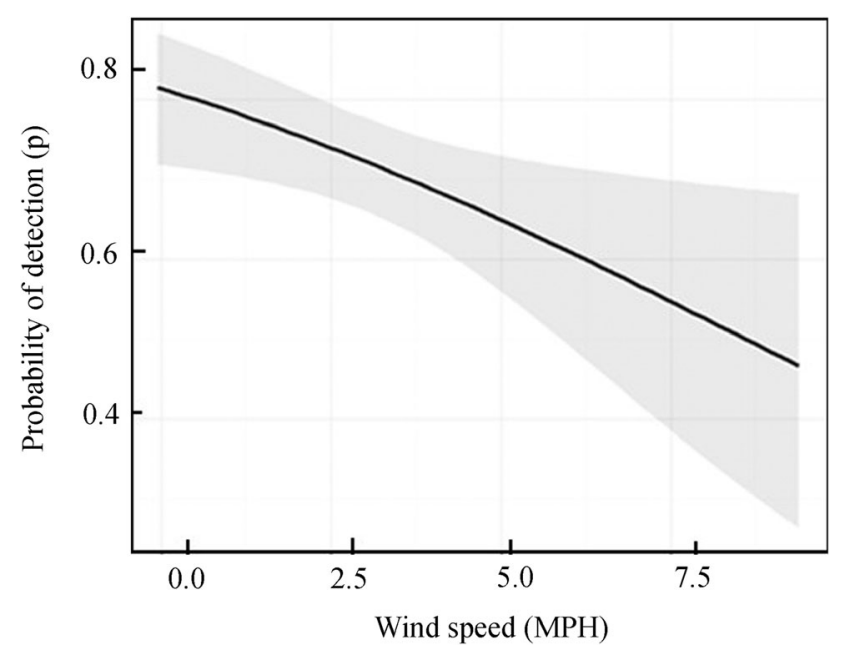

Fig. 3 Partial effects plot of the relationship between probability of detection of eastern red bats (Lasiurus borealis; with $95 \%$ confidence intervals) and mean wind speed (MPH) at Shenandoah National Park, Virginia, USA, 11 June to 15 August 2015, as identified in the averaged model

long-term ecological effect on bats in this portion of the central Appalachians. However, there was limited evidence of negative effects from time since fire for hoary bats and big brown bats. Big brown bat and hoary bat wing morphologies and lower overall echolocation frequencies are adaptations for flight and foraging in relatively uncluttered habitats (Barclay 1985; Norberg and Rayner 1985; Menzel et al. 2002), as would occur in more post-fire SNP forests than in unburned stands. Big brown bat occupancy in burned areas was related negatively to years since burn, attributable to the highest amount of fire-reduced clutter immediately post-burn, thereby facilitating flight and ease
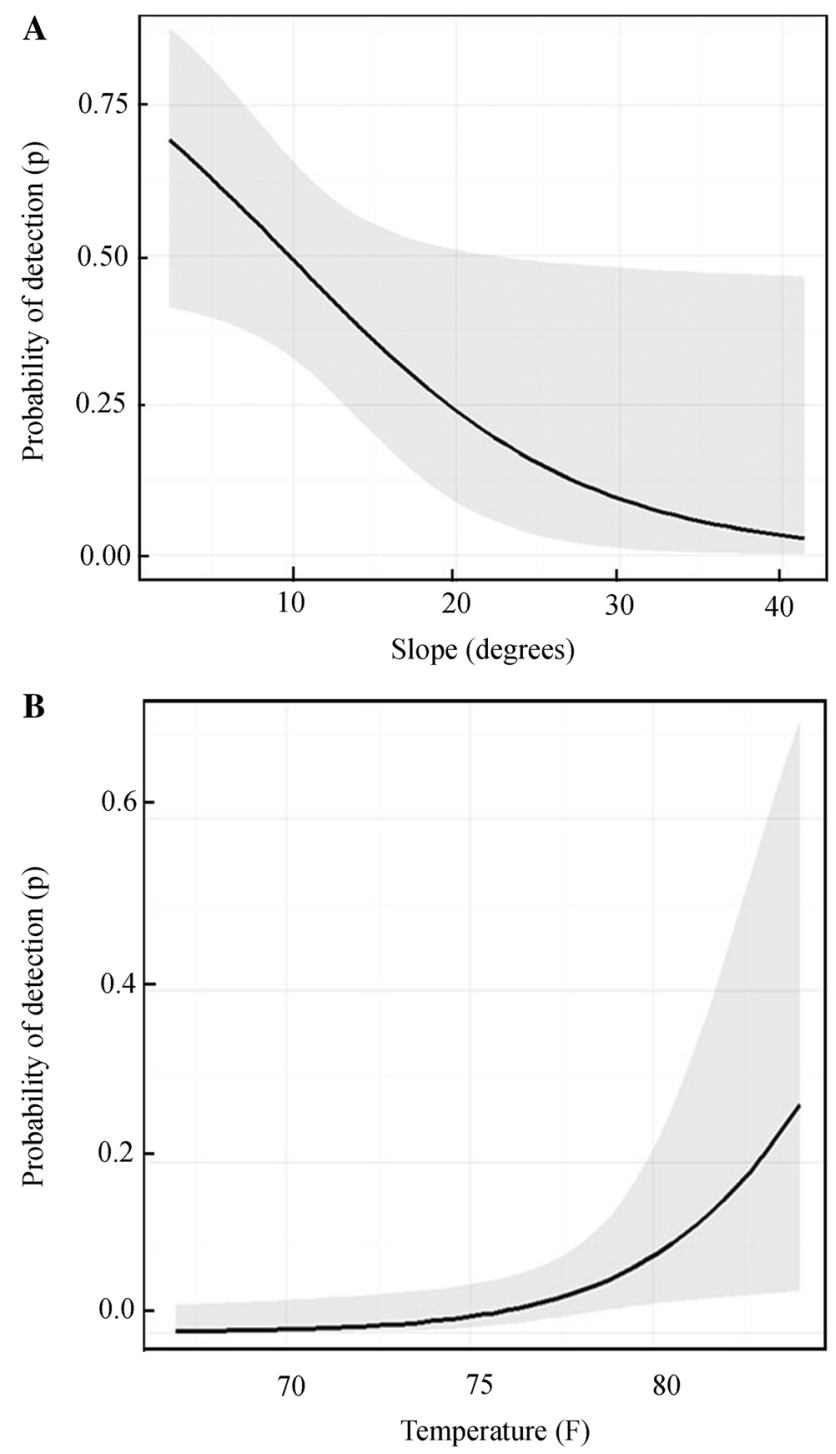

Fig. 4 a Partial effects plot of the relationship between probability of occurrence of eastern small-footed bats (Myotis leibii; with $95 \%$ confidence intervals) and slope (degrees) at Shenandoah National Park, Virginia, USA, 11 June to 15 August 2015, as identified in the averaged model. b Partial effects plot of the relationship between probability of detection of eastern small-footed bats (Myotis leibii; with $95 \%$ confidence intervals) and temperature (F) at Shenandoah National Park, Virginia, USA, 11 June to 15 August 2015, as identified in the averaged model

of foraging. Although big brown bats are considered habitat generalists (Owen et al. 2004), they readily utilize more open habitat, including that resulting from prescribed fire and forest thinning in both the central and southern Appalachians (Loeb and Waldrop 2008; Silvis et al. 2016a).

In absolute terms, big brown bat and Indiana bat occupancies were lowest in unburned habitat, intermediate in burned habitat, and highest in edge habitat. Edge sites were nearly always low-traffic, gravel roads which serve as 
Table 5 Estimates for occupancy ( $\Psi)$, detection (p), and falsepositive detection (fp), standard errors (SE), parameter type, and $95 \%$ upper and lower confidence intervals for the best supported occupancy model by species in Shenandoah National Park, Virginia, USA, 11 June to 2 August 2015

\begin{tabular}{|c|c|c|c|c|c|c|}
\hline Species & Covariate & Parameter & Estimate & SE & Lower CI & Upper CI \\
\hline \multirow[t]{3}{*}{ Eastern small-footed bat (Myotis leibii) } & Slope & $\Psi$ & -0.99 & 0.50 & -1.96 & -0.02 \\
\hline & Temperature & $\mathrm{P}$ & 1.32 & 0.59 & 0.17 & 2.47 \\
\hline & Little brown bat & $\mathrm{Fp}$ & 8.85 & 1.17 & 6.55 & 11.14 \\
\hline \multirow[t]{7}{*}{ Little brown bat (Myotis lucifugus) } & Burn condition edge & $\Psi$ & 19.10 & 30.80 & -41.32 & 79.57 \\
\hline & Burn condition burn & $\Psi$ & 19.20 & 30.80 & -41.19 & 79.68 \\
\hline & Slope & $\Psi$ & -37.00 & 56.70 & -148.1 & 74.13 \\
\hline & Burn condition edge*slope & $\Psi$ & 36.70 & 56.70 & -74.38 & 147.81 \\
\hline & Burn condition burn*slope & $\Psi$ & 36.30 & 56.70 & -74.75 & 147.44 \\
\hline & Tree density & $\mathrm{P}$ & 0.91 & 0.18 & 0.55 & 1.27 \\
\hline & Northern long-eared bat & $\mathrm{Fp}$ & 5.94 & 0.58 & 4.80 & 7.08 \\
\hline \multirow[t]{3}{*}{ Tricolored bat (Perimyotis subflavus) } & Slope & $\Psi$ & -0.83 & 0.47 & -1.75 & 0.09 \\
\hline & Tree density & $\mathrm{P}$ & 0.93 & 0.19 & 0.56 & 1.31 \\
\hline & Little brown bat & $\mathrm{fp}$ & 8.89 & 1.18 & 6.58 & 11.20 \\
\hline
\end{tabular}

The parameter type, coefficient, $S E$ standard error, and $C I$ upper and lower confidence intervals are shown Estimates for covariates with confidence intervals that do not overlap zero are highlighted in bold

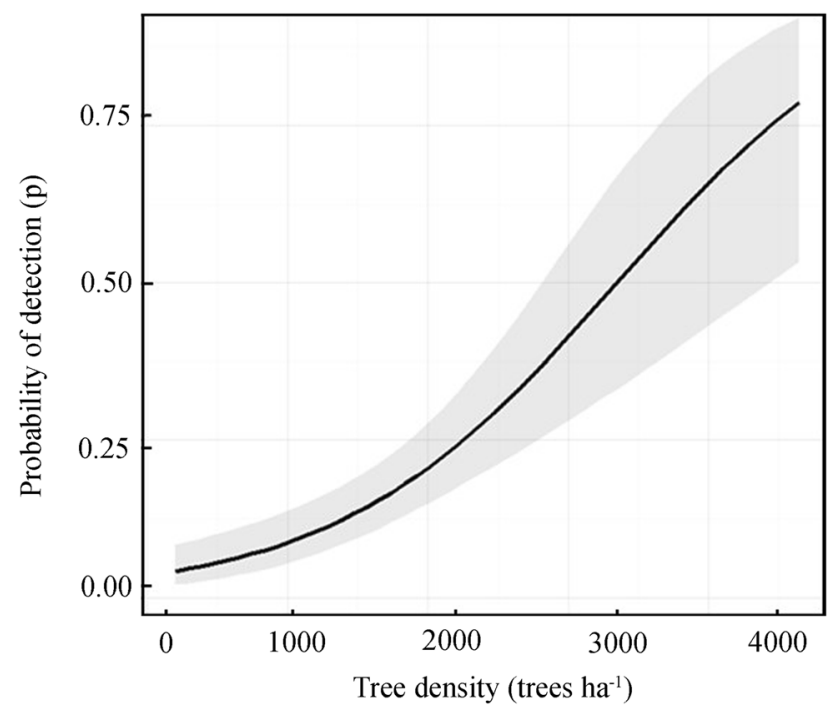

Fig. 5 Partial effects plot of the relationship between probability of detection of little brown bats (Myotis lucifugus; with 95\% confidence intervals) and tree density (trees/ha) at Shenandoah National Park, Virginia, USA, 11 June to 15 August 2015, as identified in the averaged model

firebreaks in SNP, but also provide linear corridor habitats for bats with some overstory and completely open mid-and understories. Previous studies, (Estrada 2001; Ford et al. 2006; Hein et al. 2009), have found that bat activity is high in corridors such as these that serve as efficient travel pathways for bats; it seems likely that this is also the case in SNP. Roads also provide uncluttered, wind-sheltered foraging space with vertical "sides" that provide additional

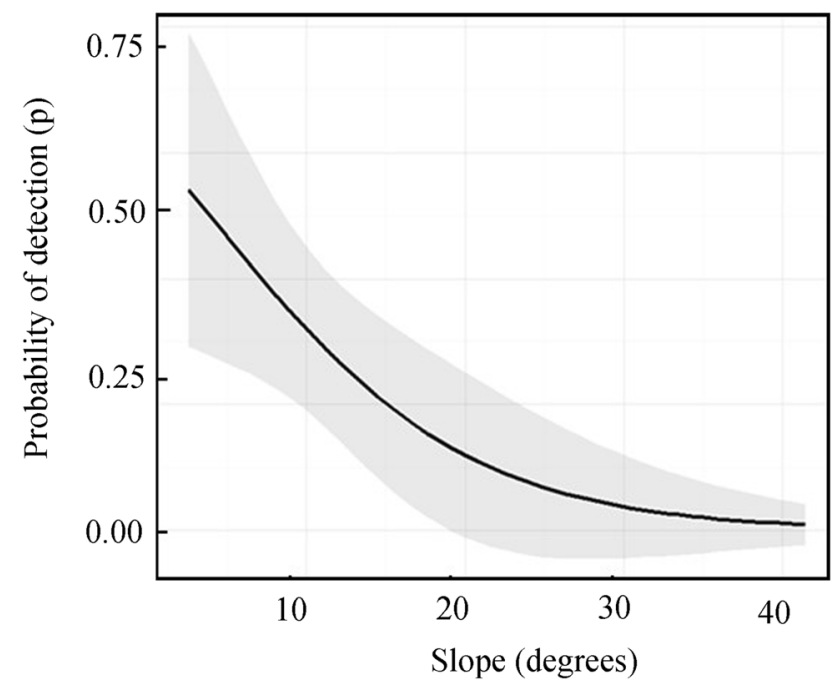

Fig. 6 Partial effects plot of the relationship between probability of occurrence of northern long-eared bats (Myotis septentrionalis; with 95\% confidence intervals) and slope (degrees) at Shenandoah National Park, Virginia, USA, 11 June to 15 August 2015, as identified in the averaged model

surface area from which bats can glean or hawk insects (Faure et al. 1993; Ratcliffe and Dawson 2003).

Hoary bat and little brown bat occupancy in each burn condition was dependent on elevation and slope, respectively. However, the relationship was weak and why this trend occurred is unclear. Little brown bat occupancy in all burn conditions had a negative relationship with slope. In edge and burned habitats, occupancy decreased steadily 


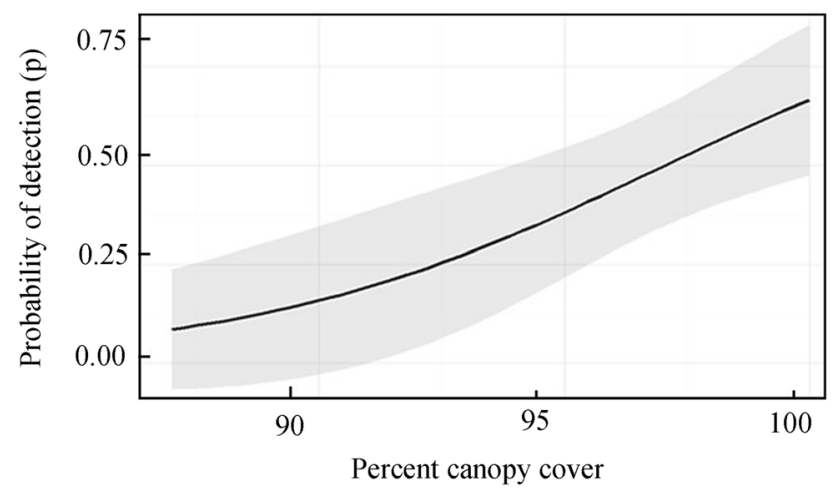

Fig. 7 Partial effects plot of the relationship between probability of detection of Indiana bats (Myotis sodalis; with 95\% confidence intervals) and percent canopy cover at Shenandoah National Park, Virginia, USA, 11 June to 15 August 2015, as identified in the averaged model

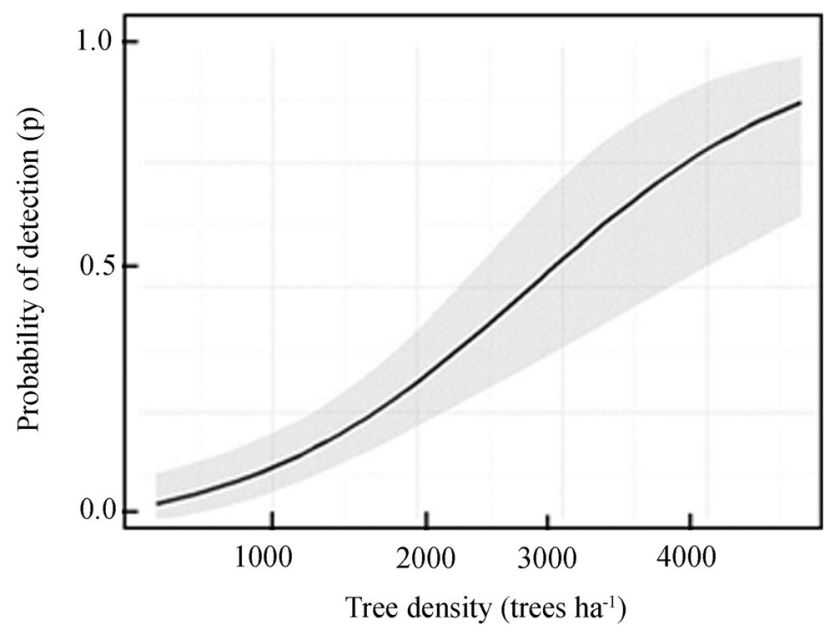

Fig. 8 Partial effects plot of the relationship between probability of detection of tricolored bats (Perimyotis subflavus; with 95\% confidence intervals) and tree density (trees/ha) at Shenandoah National Park, Virginia, USA, 11 June to 15 August 2015, as identified in the averaged model

with increasing slope but quickly dropped to zero in unburned habitat where slope exceeded $10^{\circ}$. Previous research indicates little brown bats in the central Appalachians are strongly associated with second order streams (Ford et al. 2005; Schirmacher et al. 2007; Johnson et al. 2010a). Jachowski et al. (2014) found variable effects of slope among bat species in northwestern New York, however, most trends were not statistically significant. Although slope had a small effect on little brown bat occupancy, it nonetheless was included in our confidence set of models, and had a marginally negative to negative relationship with occupancy of all Myotis species, tricolored bats, and eastern red bats. Collectively, this suggests that bats are less likely to occupy micro-habitats on steeper slopes at SNP. Our results could be a function of prey locality. In the evenings, cold-air drainage (Whiteman 2000) potentially forces prey sources uphill, suggesting that bats would forage in cove areas in the early evening, then move up the mountain as temperatures continue to fall, paradoxically, in low elevations. Conversely, bats may also avoid steep terrain due to the increased energy demands required to achieve lift (MacAyeal et al. 2011; Adams et al. 2012).

Our data suggest that single-event fires on the landscape have little to no impact on bat occupancy across species through time. Moreover, the time since fire on some of our acoustic locations invariably was so long that, to bats, these forest stands were no longer structurally or biologically different from unburned forests. Furthermore, because most of our sites at SNP were not routinely managed with fire, historically burned sites with multiple fires were not represented in our sample. Therefore, our results provide only limited information on potential temporal effects of fire. Repeated prescribed fire, such as used to restore oakdominated stands elsewhere in the central Appalachians that occur on national forest ownership, may have different effects on site occupancy by bats. Additional research on temporal effects of repeated fire is needed, as management plans incorporating prescribed fire often recommend multiple burns. For example, Hutchinson et al. (2005) found that it required multiple fires over the course of 8 years to achieve prolonged reductions in midstory tree basal area and basal sprouting.

Relative bat activity levels of WNS-affected species, while not a focal point of this study, have been documented as currently very low in the central Appalachians (Austin et al. 2018) and other WNS-affected areas (Brooks 2011; Dzal et al. 2011; Ford et al. 2011; Jachowski et al. 2014). Population declines are known to have occurred because of WNS (Reynolds et al. 2016). Although the link between abundance and occupancy is unclear, low occupancy rates in our study area likely also reflect WNS declines in bats that have occurred regionally.

Maximizing detection rates is essential in the face of WNS-related bat declines and the increasing level of effort required to detect a present species (Coleman et al. 2014). For example, we found that detection probability decreased with increasing wind speed for the eastern red bat, which is likely a function of microphone interference. Eastern small-footed bat detection probability increased with temperature, likely because of increased insect prey activity (Lemoine et al. 2014). We found detection of big brown bats, northern long-eared bats, little brown bats, and tricolored bats to be related positively to tree density. In contrast, O'Keefe et al. (2014) found an inverse relationship between detection and basal area in the southern Appalachians. It is unclear why our results differ from O'Keefe et al. (2014), but it may be because our statistical 
approach directly accounted for detection and false-positive detection. The detection of Indiana bats also increased with increasing canopy cover, which may be a function of the high canopy, characteristic of older-aged forests found in our study area, pushing bats towards detectors into the more open midstory and subsequent foraging space below. Ford et al. (2005) and Kaiser and O'Keefe (2015) found a similar relationship between Indiana bat occupancy and canopy cover in similar forest conditions.

Our application of the false-positive occupancy model provided insight into strengths and weaknesses of available automatic identification software, information critical to making appropriate decisions for study design, program selection, and interpretation of results in other settings. Given that no acoustic classifier is completely accurate, outcomes from all programs may be regarded as biased. Likewise, because classifier algorithms vary among programs, we assume that each exhibits a different bias. Use of multiple identification algorithms therefore helped us identify and protect against bias and possible limitations of individual identification packages. Our study highlights the need for continued refinement in the use of automated software identification programs relative to the effect of false-positive and false-negative determinations for sampled species. Although both programs we used have moderate to high classification accuracy rates for bat communities in the region (Ford 2014), our finding of a high likelihood of false- positive identification of Indiana bats when little brown bats were present suggests that software uses should be particularly cautious when interpreting survey results. Due to sample size limitations, not all of the false-positive covariates of interest could be considered, such as total bat community activity and total myotine activity (Broders et al. 2004; Clement et al. 2014). Further work with false-positive detections is needed both for analysis and interpretation.

Much of our current understanding of the impacts of fire in the central Appalachians and elsewhere in the East has focused on the impacts to day-roosting habitat (Boyles and Aubrey 2006; Ford et al. 2016; Johnson et al. 2009, 2010b, 2012; Silvis et al. 2016a). The response of bats to fire in terms of roost use and roost creation is wellknown and largely neutral to positive depending on the species (Ford et al. 2006, 2016; Harper et al. 2016; Johnson et al. 2009, 2010b). Our research helps clarify the impacts of fire on bat foraging habitat over long time scales. No evidence was found of fire impacts, long- or short- term, on the foraging activities of northern long-eared, tricolored, eastern small-footed, and eastern red bats, and evidence of very limited effects of fire on hoary, Indiana, big brown, and little brown bat activities, nevertheless, owing to the diversity of bat fauna and complexities of the landscape response to either wildfire or prescribed fire, as well as local complexities of forest dynamics, i.e., gap-phase processes, insect disturbance and weather (Ford et al. 2005; Patriquin et al. 2016), additional research examining fire on bat foraging and roosting habitat is warranted.

Acknowledgements M. Muthersbaugh, K. Titus, M. Sellers, and S. Hannabass provided indispensable field assistance. The use of any trade, product or firm names does not imply endorsement by the U.S. government.

\section{References}

Abrams MD (1992) Fire and the development of oak forests. Bioscience 42:346-353

Adams MD, Law BS, French KO (2009) Vegetation structure influences the vertical stratification of open- and edge-space aerial-foraging bats in harvested forests. For Ecol Manag 258:2090-2100

Adams RA, Snode ER, Shaw JB (2012) Flapping tail membrane in bats produces potentially important thrust during horizontal takeoffs and very slow flight. PLoS ONE 7:e32074. https://doi. org/10.1371/journal.pone.0032074

Aldridge HDJN, Rautenbach IL (1987) Morphology, echolocation and resource partitioning in insectivorous bats. J Anim Ecol 56:763-778

Armitage DW, Ober HK (2012) The effects of prescribed fire on bat communities in the longleaf pine sandhills ecosystem. J Mammal 93:102-114

Arnett EB, Baerwald EF (2013) Impacts of wind energy development on bats: implications for conservation. In: Adams RA, Pedersen SC (eds) Bat evolution, ecology, and conservation. Springer, New York, pp 435-456

Arnett EB, Brown WK, Erickson WP, Fiedler JK, Hamilton BL, Henry TH, Jain A, Johnson GD, Kerns J, Koford RR, Nicholson CP, O'Connell TJ, Plorkowski MD, Tankersley RD (2008) Patterns of bat fatalities at wind energy facilities in North America. J Wildl Manag 72:61-78

Austin LV, Silvis A, Ford WM, Muthersbaugh MS (2018) Bat activity following restoration prescribed burning in the Central Appalachian upland and riparian habitats. Nat Area J 38:183-195

Barclay RMR (1985) Long-versus short-range foraging strategies of hoary (Lasiurus cinereus) and silver-haired (Lasionycteris noctivagans) bats and the consequences for prey selection. Can $\mathbf{J}$ Zool 63:2507-2515

Boyles JG, Aubrey DP (2006) Managing forests with prescribed fire: implications for a cavity-dwelling bat species. For Ecol Manag 222:108-115. https://doi.org/10.1016/j.foreco.2005.09.024

Britzke ER, Duchamp JE, Murray KL, Swihart RK, Robbins LW (2011) Acoustic identification of bats in the eastern United States: a comparison of parametric and nonparametric methods. J Wildl Manag 75:660-667. https://doi.org/10.1002/jwmg.68

Broders HG, Findlay CS, Zheng L (2004) Effects of clutter on echolocation call structure of Myotis septentrionalis and $M$. lucifugus. J Mammal 85:273-281. https://doi.org/10.1644/BWG102

Brooks RT (2011) Declines in summer bat activity in central New England 4 years following the initial detection of White-nose Syndrome. Biodivers Conserv 20:2537-2541. https://doi.org/10. 1007/s10531-011-9996-0

Brose P, Schuler T, Van Lear D, Berst J (2011) Bringing fire back: the changing regimes of the Appalachian mixed-oak forests. J For 99:30-35 
Burnham KP, Anderson DR (2002) Model selection and multimodel inference: a practical information-theoretic approach, 2nd edn. Springer, New York, pp 1-488

Caceres MC, Barclay RMR (2000) Myotis septentrionalis. Mamm Species 634:1-4. https://doi.org/10.1644/1545-1410(2000)634\% 3c0001:MS\%3e2.0.CO;2

Carter TC, Ford WM, Menzel MA (2000) Fire and bats in the southeast and mid-Atlantic: more questions than answers? In: Ford WM, Russell K, Moorman CE (eds) The role of fire in nongame wildlife management and community restoration: traditional uses and new directions proceedings of a special workshop. U.S. forest service general technical report NE-288, Newtown Square, PA. pp 139-143

Clement MJ, Rodhouse TJ, Ormsbee PC, Szewczak JM, Nichols JD (2014) Accounting for false-positive acoustic detections of bats using occupancy models. J Appl Ecol 51:1460-1467

Coleman LS, Ford WM, Dobony CA, Britzke ER (2014) A comparison of passive and active acoustic sampling for a bat community impacted by white-nose syndrome. J Fish Wildl Manag 5:217-226

Cox MR, Willcox EV, Keyser PD, Vander Yacht AL (2016) Bat response to prescribed fire and overstory thinning in hardwood forest on the Cumberland Plateau, Tennessee. For Ecol Manag 359:221-231

Dickinson MB, Lacki MJ, Cox DR (2009) Fire and the endangered Indiana Bat. In: Hutchinson TF (ed) Proceedings of the 3rd fire in eastern oak forests conference. U.S. Forest Service, Northern Research Station, Newtown Square, PA, pp 51-75

Dickinson MB, Norris JC, Bova AS, Kremens RL, Young V, Lacki MJ (2010) Effects of wildland fire smoke on a tree-roosting bat: integrating a plume model, field measurements, and mammalian dose-response relationships. Can J For Res 40:2187-2203

Dzal Y, McGuire LP, Veselka N, Fenton MB (2011) Going, going, gone: the impact of white-nose syndrome on the summer activity of the little brown bat (Myotis lucifugus). Biol Lett 7:392-394

Erickson RA, Thogmartin WE, Diffendorfer JE, Russell RE, Szymanksi JA (2016) Effects of wind energy generation and white-nose syndrome on the viability of the Indiana bat. PeerJ 4:e2830. https://doi.org/10.7717/peerj.2830

Estrada A (2001) Bat species richness in live fences and in corridors of residual rain forest vegetation at Los Tuxtlas, Mexico. Ecography 24:94-102

Faure PA, Fullard JH, Dawson JW (1993) The gleaning attacks of the northern long-eared bat, Myotis septentrionalis, are relatively inaudible to moths. J Exp Biol 178:173-189

Fiske I, Chandler R (2011) Unmarked: an R package for fitting hierarchical models of wildlife occurrence and abundance. J Stat Softw 4:1-23

Ford WM, Menzel MA, Rodrigue JL, Menzel JM, Johnson JB (2005) Relating bat species presence to simple habitat measures in a central Appalachian forest. Biol Conserv 126:528-539

Ford WM, Menzel JM, Menzel MA, Edwards JW, Kilgo JC (2006) Presence and absence of bats across habitat scales in the upper coastal plain of South Carolina. J Wildl Manag 70:1200-1209

Ford WM, Rodrigue JL, Rowan EL, Castleberry SB, Schuler TM (2010) Woodland salamander response to two prescribed fires in the central Appalachians. For Ecol Manag 260:1003-1009

Ford WM, Britzke ER, Dobony CA, Rodrigue JL, Johnson JB (2011) Patterns of acoustical activity of bats prior to and following White-nose Syndrome occurrence. J Fish Wildl Manag 2:125-134

Ford WM, Silvis A, Johnson JB, Edwards JW, Karp M (2016) Northern long-eared bat day-roosting and prescribed fire in the central Appalachians, USA. Fire Ecol 12:13-27
Francl KE, Sparks D, Brack V Jr, Timpone J (2011) White-nose syndrome and wing index scores among summer bats in the northeastern United States. J Wildl Dis 47:41-48

Francl KE, Ford WM, Sparks DW, Brack V (2012) Capture and reproductive trends in summer bat communities in West Virginia: assessing the impact of White-nose Syndrome. J Fish Wildl Manag 3:33-42

Frick WF, Pollock JF, Hicks AC, Langwig KE, Reynolds DS, Turner GG, Butchkowski CM, Kunz TH (2010) An emerging disease causes regional population collapse of a common North American bat species. Science 329:679-682

Garst DW (2007) Distribution, habitat analysis, and conservation of the timber rattlesnake in Virginia. Master's thesis, Virginia Polytechnic Institute and State University, p 110. Blacksburg, Virginia

Grindal SD, Brigham RM (1998) Short-term effects of small-scale habitat disturbance on activity by insectivorous bats. J Wildl Manag 62:996-1003

Grueber CE, Nakagawa S, Laws RJ, Jamieson IG (2011) Multimodel inference in ecology and evolution: challenges and solutions. J Evol Biol 24:699-711

Harper CA, Ford WM, Lashley MA, Moorman CE, Stambaugh MC (2016) Fire effects on wildlife in the Central Hardwoods and Appalachian regions, USA. Fire Ecol 12:127-159

Hein CD, Castleberry SB, Miller KV (2009) Site-occupancy of bats in relation to forested corridors. For Ecol Manag 257:1200-1207

Hessburg PF, Spies TA, Perry DA, Skinner CN, Taylor AH, Brown PM, Stephens SL, Larson AJ, Churchill DJ, Povak NA, Singleton PH, McComb B, Zielinkski WJ, Collins BM, Slater RB, Keanem JJ, Franklin JF, Riegel G (2016) Tamm review: management of mixed-severity fire regime forests in Oregon, Washington, and Northern California. For Ecol Manag $366: 221-250$

Hessl AE, Saladyga T, Schuler T, Clark P, Wixom J (2011) Fire history from three species on a central Appalachian ridgetop. Can J For Res 41:2031-2039

Hutchinson JT, Lacki MJ (1999) Foraging behavior and habitat use of red bats in mixed mesophytic forests of the Cumberland Plateau, Kentucky. In: Proceedings 12th central hardwood forest conference. US Depatrment of Agriculture, Forest Service, Southern Research Station, p 171

Hutchinson TF, Sutherland EK, Yaussy DA (2005) Effects of repeated prescribed fires on the structure, composition, and regeneration of mixed-oak forests in Ohio. For Ecol Manag 218:210-228

Ingersoll TE, Sewall BJ, Amelon SK (2013) Improved analysis of long-term monitoring data demonstrates marked regional declines of bat populations in the eastern United States. PLoS ONE. https://doi.org/10.1371/journal.pone.0065907

Iverson LR, Hutchinson TF, Peters MP, Yaussy DA (2017) Longterm response of oak-hickory regeneration to partial harvest and repeated fires: influence of light and moisture. Ecosphere 8:e01642. https://doi.org/10.1002/ecs2.1642

Jachowski DS, Johnson JB, Dobony CA, Edwards JW, Ford WM (2014) Space use and resource selection by foraging Indiana bats at the northern edge of their distribution. Endanger Species Res 24:149-157

Jennings N, Parsons S, Pocock MJO (2008) Human vs. machine: identification of bat species from their echolocation calls by humans and by artificial neural networks. Can J Zool 86:371-377

Johnson JB, Edwards JW, Ford WM, Gates JE (2009) Roost tree selection by northern myotis (Myotis septentrionalis) maternity colonies following prescribed fire in a Central Appalachian Mountains hardwood forest. For Ecol Manag 258:233-242 
Johnson JB, Ford WM, Edwards JW, Menzel MA (2010a) Bat community structure within riparian areas of northwestern Georgia, USA. Folia Zool 59:192-202

Johnson JB, Ford WM, Rodrigue JL, Edwards JW, Johnson C (2010b) Roost selection by male Indiana Myotis following forest Fires in Central Appalachian hardwoods forests. J Fish Wildl Manag 1:111-121

Johnson JB, Ford WM, Edwards JW (2012) Roost networks of northern myotis (Myotis septentrionalis) in a managed landscape. For Ecol Manag 266:223-231

Kaiser ZDE, O'Keefe JM (2015) Factors affecting acoustic detection and site occupancy of Indiana bats near a known maternity colony. J Mammal 96:344-360

Keyser PD, Ford WM (2006) Influence of fire on mammals in eastern oak forests. In: Dickinson MB (ed), Proceedings of a conference on fire in eastern oak forests: delivering science to land managers. U.S. Forest Service General Technical Report NRSP-1, Newton Square, Pennsylvania, pp 180-190

Lacki MJ, Cox DR, Dodd LE, Dickinson MB (2009) Response of northern bats (Myotis septentrionalis) to prescribed fires in eastern Kentucky forests. J Mammal 90:1165-1175

Lemoine NP, Burkepile DE, Parker JD (2014) Variable effects of temperature on insect herbivory. PeerJ 2:e376. https://doi.org/10. 7717/peerj.376

Loeb SC, Waldrop TA (2008) Bat activity in relation to fire and fire surrogate treatments in southern pine stands. For Ecol Manag 255:3185-3192

MacAyeal LC, Riskin DK, Swartz SM, Breuer KS (2011) Climbing flight performance and load carrying in lesser dog-faced fruit bats (Cynopterus brachyotis). J Exp Biol 214:786-793. https:// doi.org/10.1242/jeb.050195

Menzel MA, Carter TC, Menzel JM, Ford WM, Chapman BR (2002) Effects of group selection silviculture in bottomland hardwoods on the spatial activity patterns of bats. For Ecol Manag 162:209-218

Miller DA, Nichols JD, McClintock BT, Campbell Grant EH, Bailey LL, Weir LA (2011) Improving occupancy estimation when two types of observational error occur: non-detection and species misidentification. Ecology 92:1422-1428

Mitchell K (2010) Quantitative analysis by the point-centered quarter method. Department of Mathematics and Computer Science, Hobart and William Smith Colleges. Available at: https://arxiv. org/pdf/1010.3303.pdf

Monadjem A, Reside A (2008) The influence of riparian vegetation on the distribution and abundance of bats in an African savanna. Acta Chiro 10:339-348

Müller J, Brandl R, Buchner J, Prezsch H, Seifert S, Stratz C, Veith M, Fenton B (2013) From ground to above canopy-Bat activity in mature forests is driven by vegetation density and height. For Ecol Manag 306:179-184

Norberg UM, Rayner JM (1985) Ecological morphology and flight in bats (Mammalia; Chiroptera): wing adaptations, flight performance, foraging strategy and echolocation. Philos Trans R Soc Lond 316:335-427

Nowacki GJ, Abrams MD (2008) The demise of fire and "mesophication" of forests in the eastern United States. Bioscience $58: 123-138$

O'Keefe JM, Loeb SC, Hill HS Jr, Drew Lanham J (2014) Quantifying clutter: a comparison of four methods and their relationship to bat detection. For Ecol Manag 322:1-9

Owen SF, Menzel MA, Edwards JW, Ford WM, Menzel JM, Chapman BR, Wood PB, Miller KV (2004) Bat activity in harvested and intact forest stands in the Allegheny Mountains. North J Appl For 21:154-159

Patriquin KJ, Lenoard ML, Broders HG, Ford WM, Britzke ER, Silvis A (2016) Weather as a proximate explanation for fission-fusion dynamics in female northern long-eared bats. Anim Behav 122:47-57

Perry RW (2012) A review of fire effects on bats and bat habitat in the eastern oaks region. In: Daniel CD, Michael CS, Stacey LC, Callie JS (eds) Proceedings of the 4th fire in eastern oak forests conference. U.S. forest service general technical report NRS-P102. pp 170-191

Perry RW, McDaniel VL (2015) Temperatures below leaf litter during winter prescribed burns: implications for litter-roosting bats. Int J Wildland Fire 24:544

Peterson DW, Reich PB (2001) Prescribed fire in oak savanna: fire frequency effects on stand structure and dynamics. Ecol Appl 11:914-927

Philippi T (2013) GRTS spatial sampling. National park service https://science.nature.nps.gov/im/datamgmt/statistics/r/ advanced/grts.cfm\#GRTScall. Accessed 13 Mar 2015

Plank M, Fiedler K, Reiter G (2012) Use of forest strata by bats in temperate forests: bats in temperate forest canopy. J Zool 286:154-162

Ratcliffe JM, Dawson JW (2003) Behavioural flexibility: the little brown bat, Myotis lucifugus, and the northern long-eared bat, $M$. septentrionalis, both glean and hawk prey. Anim Behav 66:847-856

Reynolds RJ, Powers KE, Orndorff W, Ford WM, Hobson CS (2016) Changes in rates of capture and demographics of Myotis septentrionalis (northern long-eared bat) in western Virginia before and after onset of White-nose Syndrome. Northeast Nat 23:195-204

Royle JA, Link WA (2006) Generalized site occupancy models allowing for false positive and false negative errors. Ecology $87: 835-841$

Russo D, Voigt CC (2016) The use of automated identification of bat echolocation calls in acoustic monitoring: a cautionary note for a sound analysis. Ecol Indic 66:598-602

Schirmacher MR, Castleberry SB, Ford WM, Miller KV (2007) Habitat associations of bats in south-central West Virginia. In: Proceedings Annual Conference Southeast Association Fish and Wildlife Agencies, vol 61, pp 46-52

Signell SA, Abrams MD, Hovis JC, Henry SW (2005) Impact of multiple fires on stand structure and tree regeneration in central Appalachian oak forests. For Ecol Manag 218:146-158

Silvis A, Gehrt SD, Williams RA (2016a) Effects of shelterwood harvest and prescribed fire in upland Appalachian hardwood forests on bat activity. For Ecol Manag 360:205-212

Silvis A, Perry R, Ford WM (2016b) Relationships of three species of bats impacted by white-nose syndrome to forest condition and management. U.S. Forest Service, Southern Research Station, general technical report SRS-214, Asheville, North Carolina, p 48

Smith DA, Gehrt SD (2010) Bat response to woodland restoration within urban forest fragments. Restor Ecol 18:914-923

Starbuck CA, Amelon SK, Thompson FR (2015) Relationships between bat occupancy and habitat and landscape structure along a savanna, woodland, forest gradient in the Missouri Ozarks: bat occupancy in Savannas. Wildl Soc Bull 39:20-30

Strahan RT, Stoddard MT, Springer JD, Huffman DW (2015) Increasing weight of evidence that thinning and burning treatments help restore understory plant communities in ponderosa pine forests. For Ecol Manag 353:208-220

Symonds MRE, Moussalli A (2011) A brief guide to model selection, multimodel inference and model averaging in behavioral ecology using Akaike's information criterion. Behav Ecol Sociobiol 65:13-21

Thogmartin WE, Sanders-Reed CA, Szymanski JA, McKann PC, Pruitt L, King RA, Runge MC, Russell RE (2013) White-nose 
syndrome is likely to extirpate the endangered Indiana bat over large parts of its range. Biol Conserv 160:162-172

Titchenell MA, Williams RA, Gehrt SD (2011) Bat response to shelterwood harvests and forest structure in oak-hickory forests. For Ecol Manag 262:980-988

USDA Forest Service (2006) Monongahela National Forest land and resource management plan. http://www.fs.usda.gov/Internet/ FSE_DOCUMENTS/stelprdb5330420.pdf. Accessed $28 \mathrm{Apr}$ 2015

USDA Forest Service (2014) Monitoring and evaluation report fiscal years 2008 through 2014 for the 1993 George Washington National Forest land and resource management plan and 2004 Jefferson National Forest land and resource management plan. U.S. Forest Service, George Washington-Jefferson National Forest, Roanoke, p 374

Whitaker JO, Rissler LJ (1992) Winter activity of bats at a mine entrance in Vermillion County, Indiana. Am Midl Nat 127:52-59

Whiteman DC (2000) Mountain meteorology: fundamentals and applications. Oxford University Press, New York, p 355

Young J, Fleming GP, Cass WB, Lea C (2009) Vegetation of Shenandoah National Park in relation to environmental gradients, version 2.0. National Park Service, Philadelphia, p 389
Young JA, Mahan CG, Forder M (2017) Integration of vegetation community spatial data into a prescribed fire planning process at Shenandoah National Park, Virginia (USA). Nat Areas J 37:394-405

Zahn A (1999) Reproductive success, colony size and roost temperature in attic-dwelling bat Myotis myotis. J Zool 247:275-280

Block WM, Conner LM, Brewer PA, Ford P, Haufler J, Litt A, Masters RE, Mitchell LR, Park J (2016) Effects of prescribed fire on wildlife and wildlife habitat in selected ecosystems of North America. The Wildlife Society Technical Review No. 16-01, The Wildlife Society, Bethesda, Maryland, USA

Ford WM (2014) Echolocation identification software results. Memo to Mike Armstrong, Andrew King, and Robin Niver. Interim report to the U.S. Fish and Wildlife Service, Bloomington. USDI-USGS, Ecosystem Division

Publisher's Note Springer Nature remains neutral with regard to jurisdictional claims in published maps and institutional affiliations. 